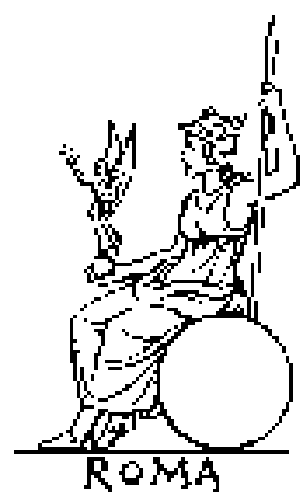

A Bronze Statuette of Zeus in the Museum at Saint-Germain Author(s): Salomon Reinach

Source: The Journal of Roman Studies, Vol. 1 (1911), pp. 64-67

Published by: Society for the Promotion of Roman Studies

Stable URL: http://www.jstor.org/stable/295849

Accessed: 12/06/2014 18:02

Your use of the JSTOR archive indicates your acceptance of the Terms \& Conditions of Use, available at http://www.jstor.org/page/info/about/policies/terms.jsp

JSTOR is a not-for-profit service that helps scholars, researchers, and students discover, use, and build upon a wide range of content in a trusted digital archive. We use information technology and tools to increase productivity and facilitate new forms of scholarship. For more information about JSTOR, please contact support@ jstor.org. 


\section{A BRONZE STATUETTE OF ZEUS IN THE MUSEUM AT SAINT-GERMAIN.}

By SALOMON REINACH.

(Plate XIII.)

In $1857, \mathrm{~J}$. F. Boudon de Saint-Amans published in Agen an illustrated octavo Essai sur les antiquités de Lot-et-Garonne. On page 198 of that work the bronze figure which we here reproduce (plate XIII) is thus described :

“Petite statue de Jupiter en bronze trouvée à Saint-Côme près d'Aiguillon. On ne saurait voir en ce genre rien de plus parfait que cette figurine . . . Cette petite statue, haute de 6 pouces, dont les yeux et les extrémités du pénis sont en or, appartient à M. le vicomte de Vivens, membre du Conseil général du departement de Lot-etGaronne."

On plate $\mathbf{2 2}$ there is a very poor outline engraving which, not knowing then the original, I caused to be reproduced in the Répertoire de la statuaire, vol. ii (1898), p. Io, no. 2.

Three years later, in July I9OI, the statuette, then belonging to the Marquis de Poyen, at Barry near Clairac (Lot-et-Garonne), was offered for sale to the national museums. I secured it for SaintGermain at the low price of I,250 francs $\left(£ 5^{\circ}\right)$ and now publish it for the first time in a manner worthy of its interest and excellence.

The statue is almost exactly I5 centimetres high, covered with a fine dark-green patina, changing to light-green on the right arm. The surface is not in a very good condition, which the photograph suffices to show. The left hand is almost detached from the arm; there is a rather large hole at the back of the left thigh. It is not true, as asserted by Boudon, that the eyes and the extremity of the penis are in gold; the latter seems to have been rubbed and glitters like pure copper; the eyes are inlaid with silver and the eyeballs are concave. I have reason to believe that the extremity of the pectorals were also in silver; but the inlaid metal has disappeared and its former presence there is only attested by two small circular depressions. 'The sandals covering the feet are very elaborate and well preserved.

There can be no doubt as to the attributes. The left hand is half opened, leaving space enough for the passage of a sceptre; the right hand clenches the handle of a thunderbolt, the lower part of which has been broken off.

The type here represented is well known and has been repeatedly studied of late. The list of replicas, given by Overbeck, ${ }^{1}$ was

\footnotetext{
${ }^{1}$ Overbeck, Kunstmytbologie, ii, 14. The first statuette in this list (formerly Pourtalès) is now in Chantilly; it was discovered at Besançon,
}

together with the archaistic Minerva published by Heuzey (Monuments Piot, vol. iv). 


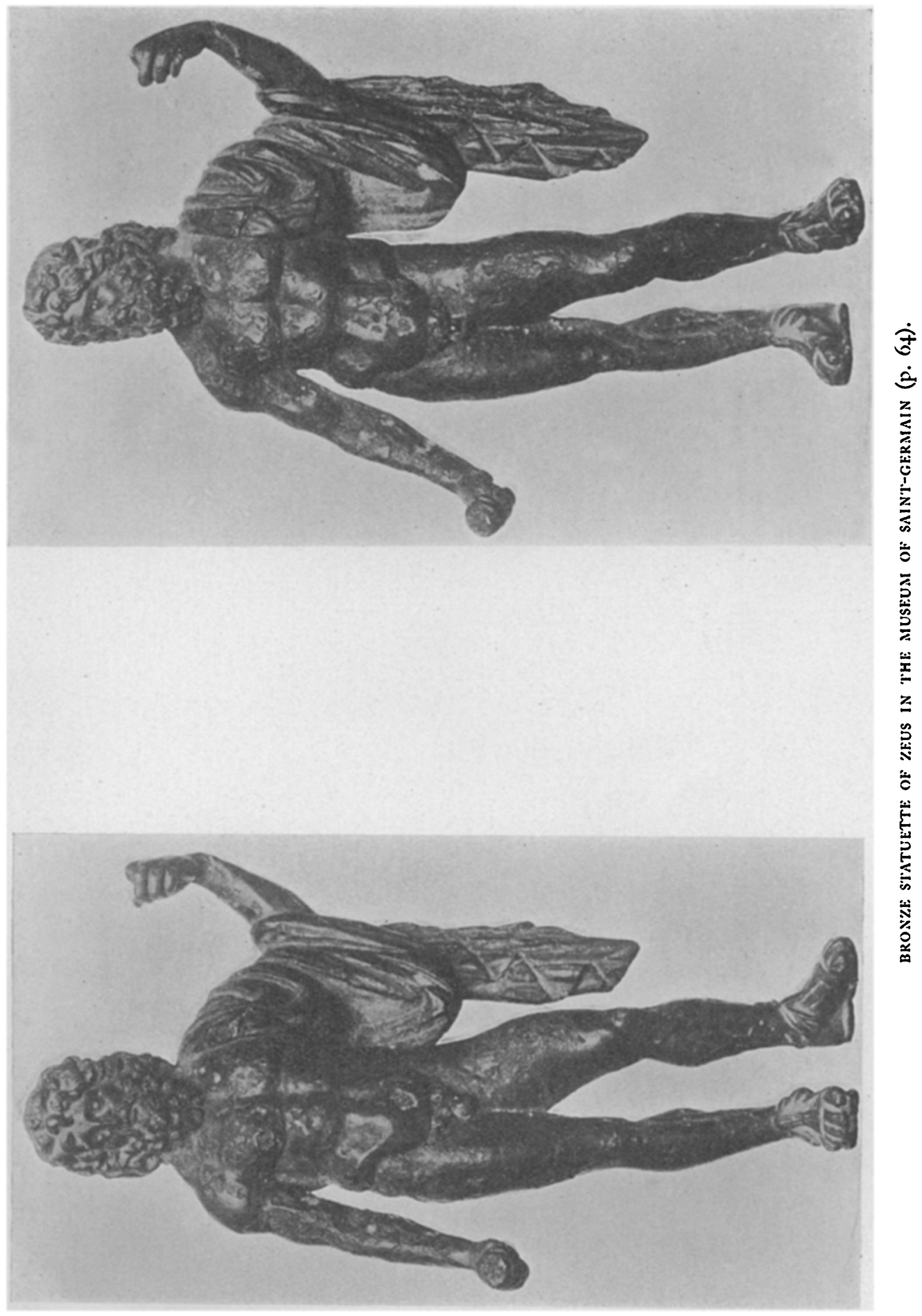


supplemented by Amelung, and could be further extended by means of my Répertoire. Hitherto, only one marble statue of that type has been discovered, the small Zeus at Palermo. ${ }^{1}$ The same motive, treated in archaistic style, appears on a well-known relief in the Vatican, decorating a candelabrum discovered in Hadrian's villa at Tibur. ${ }^{2}$ The other replicas are in bronze. ${ }^{3}$ The most elaborate and perhaps the most similar to the original is an exquisite bronze statuette in Florence, which, as Amelung has shown, is very like the Cassel Apollo, though somewhat later. ${ }^{4}$ Dr. Amelung returned to the subject in the second volume of his Sculpturen des $V$ aticanischen Museums (1908, p. 634-635), when describing the candelabrum in the Galleria delle Statue (no. 4I3). The figure of Zeus, he says, is undoubtedly from a model belonging to the third quarter of the fifth century; we still possess several copies of the original, among which is a remarkably fine and evidently Greek bronze at Florence: "The original must have been created in the time of Phidias' youth. Hauser has proved that it was known in Athens; Amelung, that it was celebrated in imperial Rome and that the type spread through the whole empire ; but we cannot name the master." Other scholars have been less reticent.

Prof. Botho Graef, ${ }^{5}$ with the assent of Furtwängler, ${ }^{6}$ brought the type in connexion with Phidias (in Verbindung mit dem phidiasischen Kreis), and Prof. Perdrizet, noticing the placid and benevolent expression of the face in the replica at Florence, assigned the original to Phidias himself. ${ }^{7}$ Furtwängler, struck by the absence of sculptural replicas, once supposed that the original might have been itself a small figure, though admitting, in a footnote, that the marble statuette at Palermo was very similar, even in detail, to the Florentine bronze. This is enough to prove that the original was not a small figure. When we further reflect that the same attitude of the arms appears in several statues of the middle of the fifth century, or Roman copies and imitations of such statues, 8 especially in the so-called Heroic King at Munich and the Apollo of the national museum in Rome, we can hardly avoid the conclusion that either Phidias or Calamis, but more probably the former, must be credited with that type of the standing Zeus, so widely imitated in the Augustan age by provincial bronze-workers. Now, as the same type appears in statues a little older than Phidias, like the Apollo in Cassel, we will readily admit that Phidias, here as in other cases, did not really create, but only modernised. A bronze statue by him would necessarily find many imitators in the

\footnotetext{
1 Arndt-Amelung, n. 547.

2 Mus. Pio Clem. iv, 2.

3 There is also an imitation on a painting (Gazette arcbéol. $188_{3}, \mathrm{pl}$. $\left.\mathrm{r}_{5}\right)$ and others on coins.

${ }^{4}$ Amelung, Florentiner Antiken, 7, and Fübrer in Florenz, 263. A good lithograph of the Floren-
} 
Augustan age; in the Hadrianic age the sculptor of the Vatican candelabrum may have indulged the spirit of archaism then prevailing in taking as a model, not the Phidiac statue, but one of its own models and predecessors. Furtwängler quite rightly remarked that the relief on the base of that candelabrum had wrongly been termed a replica by Graef, as it is " a free, strongly modified imitation, translated into a more severe style, with a quite different hair-dress and different drapery." 1 But why should we attribute such a "translation into a more severe style" to the Roman artist, instead of believing, as I do, that he reverted to an older model, say of about 450, of which the statue by Phidias was itself an adaptation?

That process of adaptation went on through the whole history of ancient art, where the modern striving for originality and unbeaten tracks was practically unknown. The provincial artists in the Augustan age did not invent eclecticism, no more than their hellenistic teachers; they simply followed the tradition. Sculptors in marble, as Furtwängler has shewn, often copied, and copied slavishly, because they used casts; but minor craftsmen who manufactured bronze statuettes for temples or private lararia must have worked from collections of drawings, which they freely modified and combined. ${ }^{2}$ That is why we possess so few small bronzes (if any) which may be considered as accurate copies of celebrated originals, and why we possess hundreds of those which are free variants of such masterpieces. If the imitations of the type of Zeus which we are dealing with were all cast and put together, we should clearly perceive that not two of them are quite alike, the bronze from Saint-Côme offering a combination of Phidiac design, Polycleitan modelling, Lysippean expression and freedom in the face, hair and beard of the god. The same holds true for the largest and finest statue of Zeus discovered in Gaul, that of Vieil-Evreux. ${ }^{3}$ When I first published a heliogravure of that splendid bronze, I declared it was Lysippean, because I had been fascinated by the head, and because Furtwängler had not yet written his Meisterwerke. Now I think that the head is Lysippean and the body Polycleitan, or, at least, derived from a fifth-century model. It is not a copy from a celebrated original, but a combination, an adaptation of a severe type to the taste of a public which was impregnated by the Greek baroque and could not renounce completely its love for effect. To use the words of Professor Michaelis, that Gaulish bronze, as so many others, is the outcome of " eine künstleriche Richtung . . . welche den Anschluss an die exemplaria graeca der klassischen Zeit mit den

1 Loc, cit. note.

2 See Furtwangler's observations about the Polycleitan bronze Hermes found in Gaul and now in the British Museum (Meisterwerke, 427).
${ }^{3}$ I published two excellent heliogravures from that statue, one in the (unfinished) Album des musées deprovince (1890), another as title-page to the Bronzes figurés de la Gaule romaine (1894). 


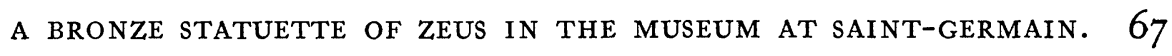
technischen und stilistischen Errungenschaften der hellenistischen Epoche verband." 1

Between Saint-Côme and Aiguillon, where the Zeus now in Saint-Germain came to light in $\mathbf{1 8 2 7}$, passes the Roman road from Bordeaux to Agen; in the immediate neighbourhood stands a massive tower, still 4 metres high and 9 metres in diameter (Boudon, 23). Aiguillon (Acilio?) was certainly the site of a Gaulish and later of a Gallo-Roman town; coins of the Volcae Tectosages have often been discovered there. ${ }^{2}$ As far as I know, no diggings have taken place and the discovery of the Jupiter was due to hazard. But the presence of such a valuable statuette, in a region where Roman bronzes are rather rare, implies the existence of a temple or, at least, of a very rich villa with a lararium on the spot.

${ }^{1}$ Fabrbuch, 1898, p. 197 .

${ }^{4}$ Dict. arch. de la Gaule, s.v. Aiguillon. 